\title{
IDENTIFICATION OF BIPOLARIS BICOLOR AND BIPOLARIS SOROKINIANA ON WHEAT SEEDS (TRITICUM AESTIVUM L.) IN BRAZIL
}

\author{
Kendra R. Morejon ${ }^{1}$; Maria Heloiza D. Moraes² ${ }^{2}$ Erna E. Bach ${ }^{3 *}$ \\ ${ }^{1}$ Instituto de Ecologia e Sistemática de Academia de Ciências de Cuba, Cuba; ${ }^{2}$ Professora do Departamento de Entomologia, \\ Fitopatologia e Zoologia Agrícola, Escola Superior de Agricultura Luiz de Queiroz, Universidade de São Paulo, Piracicaba, SP, \\ Brasil; ${ }^{3}$ Departamento Exatas, Centro Universitário Nove de Julho, São Paulo, SP, Brasil
}

Submitted: July 29, 2004; Returned to authors for corrections: February 22, 2005; Approved: May 19, 2006

\begin{abstract}
Diseases caused in wheat by Helminthosporium spp. have led to considerable yield and production losses. Different species in this genus are associated with wheat seeds. In Brazil, spot blotch in wheat is caused by Bipolaris sorokiniana (Sacc) Schoem, and another fungus Bipolaris bicolor (Mitra) Shoem that has been also isolated from wheat seeds. The current study was undertaken to identify the most frequent fungus species that normaly infects wheat seeds and compared them with B. sorokiniana. The fungus Bipolaris bicolor (Mitra) Shoem., isolated from wheat seeds cultivar IAPAR, was identified by taxonomic methods and compared with the fungus Bipolaris sorokiniana (Sacc.) Shoem., in relation to growth characteristics on the seeds, as well as to growth characteristics in PDA and morphology of the structures. Type of colony observed on the seeds is important for the differentiation between the fungus species. Bipolaris sorokiniana presented black colonies, which were well-adherent to the seeds, whereas B. bicolor presented grayish, aerial, cottonlike colonies. The size of the conidia also differed in length and width, and B. bicolor presented the smallest dimensions. In relation to septa, B. bicolor conidia presented deep ones, with dark color bases, but seldom presented dark apex. Bipolaris sorokiniana presented homogenous color.
\end{abstract}

Key words: wheat, Bipolaris bicolor, Bipolaris sorokiniana

\section{INTRODUCTION}

Helminthosporiosis causes many losses in wheat cultures. The disease is caused by Helminthosporium spp, and different species in this genus are associated with wheat seeds. Helminthosporium differs from Bipolaris, Drechslera and Exserohilum by forming parallel-walled, erect conidiophores and Bipolaris presents bipolar germination of conidia. In Brazil, spot blotch in wheat is caused by Bipolaris sorokiniana (Sacc) Schoem. Another fungi has been isolated from wheat seeds as Bipolaris bicolor (Mitra) Shoem that causes as well spot blotch but with minor lesions and can be the most deleterious disease for the producers $(7,8,10)$. Morphological characteristics such conidia (size, shape, and septation) are used as the primary characters for the practical and working identification of Bipolaris genus (1). The present work was conducted to study morphological and cultural characters from wheat seed isolates such as B. bicolor and compared with B. sorokiniana.

\section{MATERIALS AND METHODS}

Sanitary analysis of the wheat seeds cultivar IAPAR was performed using the filter paper method and freezing, procedure recommended by the Standard Methods for Seed Analysis (4). After incubation, the identification of the fungi from the seeds was performed by means of mycelial growth, using a Wild M400 stereomicroscope (Wild mod WMS02 and with Wild MPS 55 automatic camera) and conidia, conidiophores by light microscopy (Carl Zeiss, SV-11).

*Corresponding Author. Mailing address: Rua Evangelista de Souza, 1352, Parque Novo Oratório. 09260-411, Santo André, SP, Brasil. E-mail: ernabach@uol.com.br 
Conidia of each isolates were transferred to a Petri dish containing solid medium PDA (potato dextrose agar), incubated at $25^{\circ}$ to $28^{\circ} \mathrm{C}$, under alternating light $(12 \mathrm{~h}$ white fluorescent light / 12h dark). Six plates of PDA were produced for each species.

On the $7^{\text {th }}$ day of incubation, conidia were removed from the substrate using distilled water and placed on glass slides in order to assess the origin of the hilum and to determine the average size of 100 conidia and conidiophores, using a Carl Zeiss light microscope ( $\mathrm{x} 400$ to $\mathrm{x} 800$ ). Colonies were also described in relation to their growth on the culture medium, in order to draw a comparison between the species studied. The key proposed by Ellis (6) and the report by Chidambaram (5) were used in the identification of the species.

\section{RESULTS AND DISCUSSION}

Bipolaris was observed in wheat seeds originated from different places under microscopy and then obtained 10 isolates from B. sorokiniana and six isolates from B. bicolor. After 7 days in medium PDA were observed the aspect of development in medium.

\section{Macroscopic morphology}

$B$. sorokiniana and B. bicolor colonies were differentiated on wheat seeds (Fig. 1 A, B) and the following characteristics
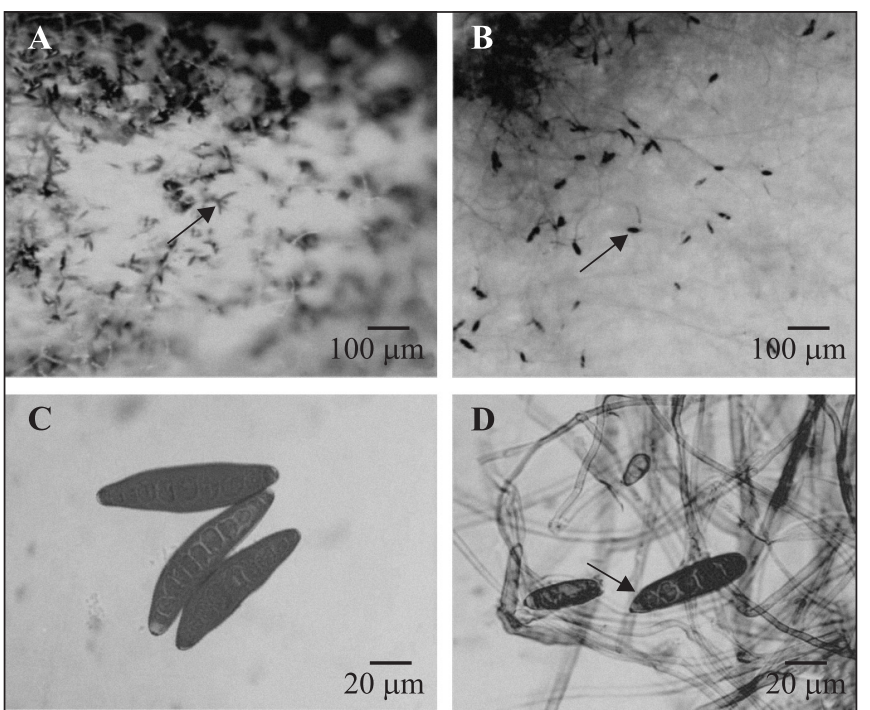

[A]- B. sorokiniana and arrow indicating the conidia on the seeds with short conidiophores, black and shiny conidia;

[B]- B. bicolor and arrow indicating the conidia on the seeds with abundant aerial mycelium and sparse conidia on the mycelium; [C]-B. sorokiniana, aspect of conidia;

[D]- B. bicolor, aspect of conidia.

Figure 1. Observation of conidia in wheat seeds under microscopy. were used: B. sorokiniana - black, velvet-like colonies, mycelium practically absent, and close to the seed, short conidiophores, black and shiny conidia. B. bicolor - gray, cotton-like colonies, abundant aerial mycelium, sparse conidia on the mycelium.

Bipolaris colonies grow rapidly in PDA media, reaching a diameter of 3 to $9 \mathrm{~cm}$ following incubation at $25^{\circ} \mathrm{C}$ for 7 days on potato dextrose agar. The colony becomes mature within 5 days.

Observations on petri plates were:

Bipolaris sorokiniana - colonies were velvet-like, dark olive; plane, totally covered by short conidiophores, with black conidia in their apex. Conidia reflected the light and gave the colony a shiny appearance. The reverse side of the colony was dark olive (Fig. 2 A).

Bipolaris bicolor presented two types of colony. The type I - velvet-like, dark olive, plane colonies, totally covered by conidia. Mycelium was absent. Colonies were very similar to what is generally described for B. sorokiniana. Reverse side presents different zones, with alternation of dark olive and light brown sections (Fig. 2 B), and the type II - dark olive and slight cotton-like colonies. The reverse side was the same color, and presents a grayish dark olive halo involving the central area (Fig. 2C). Colonies in PDA presented some differences. However, the characteristic of the colony could not be used as a

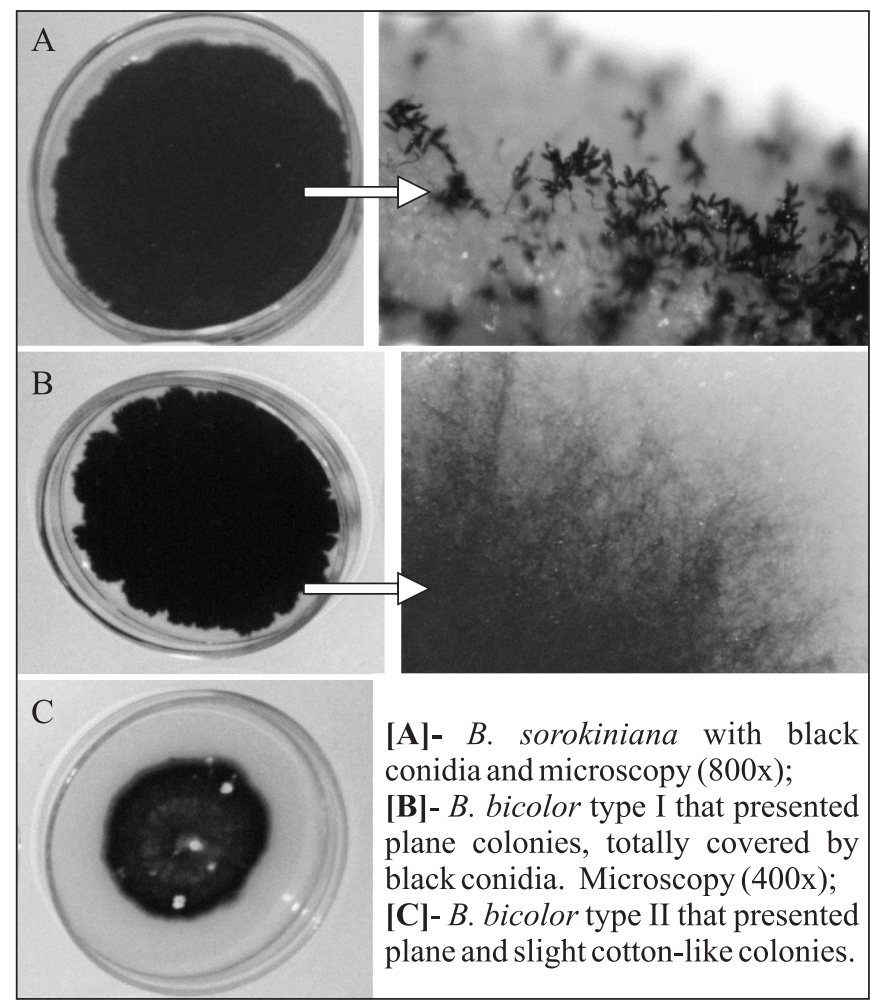

Figure 2. Development of B. sorokiniana and B. bicolor in solid medium PDA after 7 days from inoculation. 
measurable constant standard, once appearance and color intensity may vary with the isolate, due to the heterokaryotic condition of fungi in nature.

\section{Microscopic morphology}

B. sorokiniana conidia were longer than $75 \mu$ and less than $20 \mu$ wide. Pseudosepta were present at any age (Fig. 1C).

B. bicolor conidia size ranged from 40 to $78 \mu$ long and from 12.1 to $17.3 \mu$ wide. It presented 5 to 9 pseudosepta, generally six. They were straight, ellipsoid, with round edges, occasionally similar to an inverted club, rarely curve, from medium brown to dark brown in color. In more advanced developmental stages, cells from the edges tend to become more hyaline and pseudosepta in these cells seemed to be thicker, whereas the central part became almost black and made pseudosepta impossible to count (Fig. 1D). Results of the observations on $B$. bicolor are in accordance with the description by Morejón (9), who reported the same characteristics of the fungus causing leaf spot in peachpalm.

Although B. bicolor and B. sorokiniana conidia may present some similarities in relation to shape and color, when microscopically examined for the first time, conidia of the second species are larger and longer. However, this characteristic may sometimes be confusing, due to superposition in the variations among isolates.

Other characteristics that aided the identification for both were: B. bicolor and B. sorokiniana conidiophores were long, and reached $400 \mu$ long and $5.5-10 \mu$ wide. They were as well flexible, smooth, septated, and medium to dark brown. They were repeatedly geniculated in the terminal edge, presenting pores or scars at short intervals, which indicated the sites conidiophores were produced. They presented conidiogenous polytretic, integrated, terminal, intercalary and cicatrized cells.

Bipolaris sorokiniana (teleomorph Cochliobolus sativus) is the causal agent of common root rot, leaf spot disease, seedling blight, head blight, and black point of wheat and barley. The fungus is one of the most serious foliar disease constraints for both crops in warmer growing areas and causes significant yield losses.

However, we have isolated in wheat seeds B. bicolor which was considered to be pathogenic in Cuba (9). In that country, it has been isolated from leaf lesions in sugar cane, occuring under climatic conditions similar to those reported by Mehta (8) and Reis $(10,11)$, which are the most propitious conditions for the incidence of helmintosporiosis in wheat. According to Chidambaram (5), B. bicolor is knowingly pathogenic in some countries, and may produce coleoptile rot and darkening of the roots in wheat. Bach et al. (2) demonstrated that five isolates from $B$. bicolor, when at $10^{5}$ conidia suspension was used in wheat plants in a greenhouse, spot bloth on leaves was observed. Bach and Kimati (3) also demonstrated that Bipolaris bicolor from wheat was differentiated from others Bipolaris with esterase electrophoretic analysis. So, the isolates of $B$. sorokiniana was the most serious disease in wheat plants in this country but, isolates of $B$. bicolor can also presented pathogenicity when in Brazil the climatic conditions was ideal for the outbreak of the disease and we have a problem in a once more pathogenic disease.

\section{ACKNOWLEDGEMENTS}

Acknowledgements to Latin American Society of Botany for the financial supports at Department of Entomology, Phytopathology and Zoologie (Prof. Hiroshi Kimati) from ESALQ/USP, SP, Brazil, where are developed the work.

\section{RESUMO}

\section{Identificação de Bipolaris bicolor e Bipolaris sorokiniana sobre sementes de trigo (Triticum aestivum L.) no Brasil}

Doenças causadas por Helminthosporium spp. em trigo, causam consideráveis perdas na produção. Diferentes espécies do gênero do fungo podem ser encontradas em sementes. No caso do Brasil, a mancha foliar do trigo tem sido causada por Bipolaris sorokiniana (Sacc) Schoem, entretanto, outro fungo como Bipolaris bicolor (Mitra) Shoem tem sido isolado de sementes do trigo. O objetivo do presente trabalho foi identificar as espécies de fungo que normalmente infectam sementes de trigo e comparar com a mais comum B. sorokiniana. O fungo Bipolaris bicolor (Mitra) Shoem., isolado de sementes de trigo var. IAPAR, foi identificado por métodos taxonômicos e comparado com o fungo Bipolaris sorokiniana (Sacc.) Shoem. em relação ao crescimento sobre as sementes bem como às características culturais no meio BDA e morfologia das estruturas. O tipo de colônia observada sobre as sementes é importante para diferenciar as espécies entre si. O fungo $B$. sorokiniana apresentou colônias de cor preta sendo bem aderidas às sementes, enquanto $B$. bicolor apresentou colônias aéreas acinzentadas e com aspecto cotonoso. $\mathrm{O}$ tamanho dos conídios também diferenciaram no comprimento e largura onde os valores menores corresponderam a B. bicolor. Em relação aos septos, os conídios de B. bicolor apresentavam septo "profundo", com coloração escura na base e, raras vezes no ápice. Os conídios de B. sorokiniana apresentaram coloração homogênea.

Palavras-chave: trigo, Bipolaris bicolor, Bipolaris sorokiniana

\section{REFERENCES}

1. Alcorn, J.L. The taxonomy of Helminthosporium species. Annu. Rev. Phytopathol., Palo Alto, 26, 37-56, 1988. 
2. Bach, E.E.; Barros, B.C.; Kimati, H. Induced Resistance against Bipolaris bicolor, Bipolaris sorokiniana and Drechslera tritici-repentis in Wheat Leaves by Xantham Gum and Heat-Inact ivated Conidial Suspension. J. Phytopathol., 151, 1-8, 2003.

3. Bach, E.E.; Kimati, H. Esterase electrophoretic analysis to distinguish isolates between Bipolaris spp. and Drechslera tritici-repentis from wheat. World J. Microbiol. Biotechnol., 20, 199-202, 2004.

4. BRASIL. Ministério da Agricultura. Secretaria Nacional de Defesa Agropecuária. Regras para Análise de Sementes. Brasília, 1992, $364 \mathrm{p}$.

5. Chidambaram, P.; Mathur, S.B.; Nergaars, P. Identification of seedborne Drechslera spp. In: International Seed Testing Association (ISTA) Handbook on Seed Health Testing, Bassersdorf Suiça, 1, 165-207, 1973.
6. Ellis, M.B. Dematiaceous Hyphomycetes. Commonwealth Mycological Institute, Kew, Surrey, England, 1971, 609p.

7. Luz, W.C. Identificação dos principais fungos das sementes de trigo. Circular Técnica - EMBRAPA - MA - CNPT, 1987, 20p.

8. Mehta, R.Y. Doenças do trigo e seu controle. São Paulo: Agronômica Ceres, 1978, 190p.

9. Morejón, K.R.; Kimati, H.; Fancelli, M.I. Bipolaris bicolor (Mitra) Shoemaker: species associated to foliar spot in pupunha palm (Bactris gasipaes Kunth) in Brazil. Rev. Iberoam. Mycol., Cuba, 15, 55-57, 1998.

10. Reis, E.M. Doenças do trigo: podridão comum de raízes. São Paulo, CNDA. 1985, 43p

11. Reis, E.M. Patologia de sementes de cereais de inverno. São Paulo, CNDA, 1987, 32p. 